Jan Halberda

Uniwersytet Jagielloński e-mail: jan.halberda@uj.edu.pl telefon: +48124221032

DOI: 10.15290/mhi.2015.14.01.12

\title{
Fibrosa S.A. v. Fairbairn Lawson Combe Barbour Ltd (1942). Spółka z Kresów przed Izbą Lordów
}

\begin{abstract}
SUMMARY
Fibrosa S.A. v. Fairbairn Lawson Combe Barbour Ltd (1942). The Company from Kresy (Polish Eastern Borderlands) Before the House of Lords

The paper discusses Fibrosa S.A. v. Fairbairn Lawson Combe Barbour Ltd (1942), a case considered as one of several landmark cases in the English law of restitution. What was at stake in litigation before the House of Lords was whether a Polish plaintiff should recover a prepayment transferred pursuant to a contract that had become frustrated because of the outbreak of war in 1939. The lords had to decide on the application of two potentially dissonant doctrines - frustration and total failure of consideration. But what made the Fibrosa case famous was an obiter dictum delivered by lord Wright. This eminent judge declared that English law should provide remedies for unjust enrichment. That is the very reason why the case is still being cited by the lawyers today.
\end{abstract}

Key words: legal history, England, English law, common law, restitution, unjust enrichment

Słowa kluczowe: historia prawa, Anglia, bezpodstawne wzbogacenie, common law

Zastanawiając się nad tym, jakiemu zagadnieniu poświęcić artykuł składany do niniejszego tomu, dedykowanego Panu Profesorowi Adamowi Lityńskiemu, zorientowałem się, że Jubilat pochodzi z Kresów - urodził się we Lwowie. Z tej przyczyny ostateczny wybór padł na problematykę prowadzonego przed angielską Izbą Lordów procesu w sprawie Fibrosa S.A. v. Fairbairn Lawson Combe Barbour Ltd (1942) ${ }^{1}$, w której powodem była fabryka mająca siedzibę również na Kresach - w Wilnie.

1 Fibrosa Spolka Akcyjna v. Fairbairn Lawson Combe Barbour Ltd (1943) A.C. 32 (zob. także: G. McMeel, Casebook on restitution, London 1996, s. 16-18, 251-256). Wyrok w tej sprawie zapad1 w 1942 r., a rok $1943 \mathrm{w}$ nawiasie to data roczna publikacji w reports. 
Rozstrzygnięcie zapadłe $\mathrm{w}$ tej sprawie uznawane jest za jedno $\mathrm{z}$ leading cases, które wywarły poważny wpływ na kształt współczesnego prawa angielskiego w zakresie bezpodstawnego wzbogacenia (law of restitution). Fragmenty uzasadnienia wyroku sporządzone przez lorda Wrighta w znacznym stopniu umożliwiły porzucenie obowiązującego dotąd przez common law w common law podziału zobowiązań na pochodzące $\mathrm{z}$ umów i z deliktów oraz uznanie bezpodstawnego wzbogacenia za trzecie możliwe źródło ich powstania. Kazus Fibrosy znalazł się w opublikowanej kilka lat temu książce Landmark cases in the Law of Restitution ${ }^{2}$.

\section{Stan faktyczny}

Spółka działająca pod nazwą Fabryka Zakłady Lniarskie Fibrosa Spółka Akcyjna $\mathrm{w}$ Wilnie ${ }^{3}$ złożyła zamówienie na przędzalnię maszynową. Za pośrednictwem brytyjskiego agenta (British and Foreign Trading Co.) podpisała 12 lipca 1939 r. umowę z działającym w Leeds przedsiębiorstwem Fairbairn Lawson Combe Barbour Limited. Brytyjczycy - za cenę 4.800 funtów - zobowiązali się do wyprodukowania maszyn, przetransportowania ich drogą morską do Gdyni ${ }^{4}$, a w końcu nadzorowania montażu na miejscu w wileńskiej fabryce. Ustalono, że jedna trzecia ceny zostanie zapłacona od razu przy zawarciu umowy, zaś pozostała część po wykonaniu wszystkich prac. Fibrosa zapłaciła 1.000 funtów.

Wybuch wojny 1 września 1939 r. uniemożliwił wykonanie umowy. Gdynia, dokąd miał dotrzeć statek z towarem, została opanowana przez wojska niemieckie już 14 września, a Wilno - miejsce montażu maszyn - przez radzieckie 19 września 1939 r. ${ }^{5}$ Po przystąpieniu Wielkiej Brytanii do wojny z Trzecią Rze-

2 Landmark cases in the Law of Restitution, red. Ch. Mitchell, P. Mitchell, Oxford 2006.

3 Ta pełna nazwa znalazła się w wydawanych w Warszawie pod niemiecką okupacją Wiadomościach Urzędu Patentowego (z. 2 z 31 lipca 1940 r., s. 47, z. 3 z 31 sierpnia 1940 r., s. 67). W nauce angielskiej spółka ta funkcjonuje pod skróconą i ogołoconą z polskich znaków nazwą Fibrosa Spolka Akcyjna (tak chociażby w treści wyroku Izby Lordów). Relacja z procesu przed Sądem Apelacyjnym posługuje się francuskim oznaczeniem formy prawnej: Fibrosa Societe Anonime. W literaturze występuje również forma: Fibrosa S.A.

4 W kontrakcie posłużono się klauzulą CIF (INCOTERMS), a zatem Fairbairn pokrywał koszty ubezpieczenia i frachtu do Gdyni.

5 Oficjalna relacja z procesu przed Izbą Lordów podaje błędnie wiele dat: zajęcia Gdyni przez Niemców 23 - zamiast 14 - września 1939 r., wkroczenia wojsk sowieckich do Polski 16 - zamiast 17 - września 1939 r., oraz inkorporacji Litwy do Związku Radzieckiego sierpień - zamiast 15 czerwca - 1940 r. (Fibrosa S.A., (1943) A.C. 33, 35). Dokładne daty zajęcia obu miast mogły pewnie nie być znane brytyjskim prawnikom w 1942 r. Trudno natomiast usprawiedliwić błąd występujący w pracy współczesnego cywilisty podającego, że najazd niemiecki na Polskę miał miejsce pod koniec sierpnia 1939 r. (P. Mitchell, Fibrosa Spolka Akcyjna v Fairbairn Lawson Combe Barbour, Limited (1942), [w:] Landmark cases..., s. 267). 
szą brytyjski parlament przyjął ustawę o stosunkach gospodarczych z wrogiem. $\mathrm{W}$ myśl jej przepisów pozostawanie w stosunkach gospodarczych z wrogiem, przez co rozumiano dostawę towaru, dokonanie zapłaty, świadczenie usług (sekcja 1 (2) a) ustawy), stanowiło przestępstwo. Spółka Fairbairn nie mogła dokonać dostawy maszyn do Gdyni, ponieważ ta była zajęta przez Niemców ${ }^{6}$. Nastąpił impas.

Skoro tak, to Fibrosa wystąpiła 1 maja 1940 r. $^{7}$ z powództwem przeciwko Fairbarn o zapłatę odszkodowania za niewykonanie umowy oraz o nakazanie jej wykonania lub - ewentualnie - o zwrot zaliczki (z odsetkami) wobec wygaśnięcia umowy. Powództwo zostało $\mathrm{w}$ dwóch instancjach oddalone (7 marca 1941 r., 15 maja 1941 r.), zaś korzystne orzeczenie wydała dopiero Izba Lordów jako najwyższa instancja wymiaru sprawiedliwości.

Na tym etapie procesu zorientowano się, że w myśl wspomnianej ustawy konieczne jest uzyskanie przez Fibrosę zezwolenia Ministerstwa Handlu (Board of Trade) na dalsze prowadzenie postępowania. Za wroga traktowano bowiem spółki, których siedziby znajdowały się na terenie okupowanym przez wroga (s. 2 (1), s. 15 (1)). Przed sądami niższych instancji nie rozważano statusu Fibrosy jako wroga. Siedziba spółki pozostawała na terenach radzieckiej okupacji, następnie Wilno należało do Litwy, potem do Związku Radzieckiego. Dopiero zajęcie miasta przez Wehrmacht 24 czerwca 1941 r., w trzecim dniu operacji Barbarossa, było jednoznaczne z zakwalifikowaniem Fibrosy jako wroga. Specjalne zezwolenie zostało spółce przyznane (17 kwietnia 1942 r.), co umożliwiło dalsze procedowanie ${ }^{8}$.

\section{Frustration w I połowie XX w. - procesy koronacyjne}

Przedmiotem apelacji kierowanej przez Fibrosę do Izby Lordów była wyłącznie kwestia zwrotu zaliczki ${ }^{9}$. Dotychczasowe common law w tym zakresie ukształtowane zostało na gruncie tzw. procesów koronacyjnych (coronation cases).

Do najbardziej znanych spośród nich należą Krell v. Henry (1903) i Chandler v. Webster (1904). W dniu 26 czerwca 1902 r. miała odbyć się uroczysta koronacja Edwarda VII (1902-1910). Właściciele kamienic znajdujących się

6 Trading with the Enemy Act (1939) 2\&3 George VI c. 86. Fibrosa S.A., (1943) A.C. 34, 41 (Viscount Simon L.C.).

7 Fibrosa S.A., (1943) A.C. 34. Odmiennie P. Mitchell (op. cit., s. 267), który datuje złożenie pozwu na marzec $1941 \mathrm{r}$.

8 Fibrosa S.A., (1943) A.C. 35.

9 Ibidem. 
wzdłuż trasy przemarszu oferowali - za stosowną zapłatą - możliwość przyglądania się uroczystości z okien lub balkonów. Planowana koronacja została jednak odwołana z powodu choroby Edwarda. Tymczasem już wcześniej zawarto wiele umów najmu miejsc widokowych. Uznano, że odwołanie koronacji spowodowało wygaśnięcie umów. Wyrok w sprawie Chandler v. Webster (1904) stanowił aż do lat czterdziestych wiążący precedens określający przesłanki oraz skutki stosowania instytucji frustration odnoszącej się do wygaśnięcia z mocy prawa umowy w razie wystąpienia niezawinionej następczej niemożliwości jej wykonania.

Powodem $\mathrm{w}$ tej sprawie był najemca domagający się zwrotu czynszu zapłaconego z góry. Wskazywał, że uroczystość, za której oglądanie zapłacił, nie odbyła się. Powoływał się na funkcjonującą w orzecznictwie od początku XVIII w. koncepcję total failure of consideration, a zatem zupełnego upadku przyczyny, dla której świadczono ${ }^{10}$.

Mimo tej argumentacji Sąd Apelacyjny oddalił powództwo, zwracając uwagę, że umowa została zawarta w sposób prawidłowy, była ważna, a dopiero okoliczności następcze i od stron niezależne wywołały niemożliwość jej wykonania, a w rezultacie - wygaśnięcie (frustration). Konsekwencje frustration należało ustalać na podstawie analizy postanowień umowy zawartej między stronami, a w ich braku implikować je w drodze wykładni treści oświadczeń woli stron. Akcentowano zatem perspektywę kontraktową, a nie restytucyjną. Sąd w osobie sędziego Collinsa M.R. (Master of Rolls) wskazywał, że - pozwalająca na restytucję świadczenia - doktryna total failure of consideration może zostać zastosowana tylko $\mathrm{w}$ razie nieważności umowy ab initio, a nie wtedy, gdy traci ona moc wyłącznie ze skutkiem na przyszłość (frustration). Wobec tego $\mathrm{w}$ razie frustration świadczenia spełnione przed wygaśnięciem umowy nie powinny być zwracane („the loss lies where it falls") $)^{11}$.

\section{Przebieg procesu}

Wyrok Chandler v. Webster (1904) traktowano wciąż w latach czterdziestych jako wiążący precedens. Skoro zaś wybuch II wojny światowej doprowadził do niemożliwości wykonania umowy łączącej Fairnbarn z Fibrosą i w kon-

10 Dutch v. Warren (1720) Strange I 406, anon. (1721) Strange I 407 (J. Strange, Reports of Adjudged Cases In the Courts of Chancery, King's Bench, Common Pleas and Exchequer, From Trinity Term in the second Year of King George I To Trinity Term in the twenty-first Year of King George II, Savoy (London) 1755).

11 Krell v. Henry (1903) 2 K.B. 740, Chandler v. Webster (1904) 1 K.B. 493. A. Burrows, A Casebook on Contract, Oxford 2009, s. 679-680; R. Evans-Jones, Roman Law in Britain, [w:] Questiones Iuris. Festschrift fur Joseph Georg Wolf zum 70. Geburtstag, red. U. Manthe, C. Krampe, Berlin 2000, s. 86-87; P. Mitchell, op. cit., s. 248-249. 
sekwencji do jej wygaśnięcia, to świadczenia dokonane do tej pory nie powinny podlegać zwrotowi. Dlatego prima facie powództwo Fibrosy skazane było na niepowodzenie.

\section{a) Wybór prawa}

Takie rozstrzygnięcie mogłoby wydawać się nam zaskakujące. Gdyby bowiem w sprawie zastosować prawo polskie, czy to według stanu na 1 września 1939 r. czy choćby na 1 stycznia 2015 r., uzyskalibyśmy inny - bardziej sprawiedliwy i przekonujący - wynik. Stwierdzilibyśmy, że, po pierwsze, wobec następczej niemożliwości wykonania zobowiązania niezawinionej przez żadną ze stron umowa wygasła; po drugie ten, kto otrzymał świadczenie (czyli Fairnbarn) obowiązany jest do jego zwrotu; po trzecie zwrot powinien nastąpić zgodnie $\mathrm{z}$ zasadami bezpodstawnego wzbogacenia, a zatem $\mathrm{z}$ uwzględnieniem poniesionych $\mathrm{w}$ toku realizacji umowy wydatków (art. 267 §1-\$2 w związku z art. 129 in principio i art. $133 \S 1$ kodeksu zobowiązań, art. $495 \S 1$ kodeksu cywilnego).

W sprawie zastosowano jednak niekorzystne dla powoda prawo angielskie, co wynikało z regulacji prawa prywatnego międzynarodowego. Strony zapewne $\mathrm{w}$ umowie dokonały wskazania prawa (tego nie wiemy, a wyrok Izby Lordów nie odnosi się w ogóle do problematyki kolizjonistycznej). W braku takiego wyboru za właściwe (proper law of contract) należało uznać prawo angielskie jako prawo sprzedawcy ${ }^{12}$. Biorąc pod uwagę brak możliwości wyegzekwowania w Wielkiej Brytanii wyroku, który zostałby wydany podczas wojny $\mathrm{w}$ Wilnie, jedynym praktycznym rozwiązaniem było zainicjowanie procesu przeciwko Fairnbarn właśnie przed sądem angielskim ${ }^{13}$.

\section{b) Argumenty Fibrosy}

Mimo niewielkich szans na odzyskanie zaliczki prawnicy Fibrosy podjęli próbę pozbawienia mocy precedensu Chandler v. Webster (1904). Wskazywali, że procesy koronacyjne zostały błędnie rozstrzygnięte. Podnosili, iż mimo wystąpienia frustration należało $\mathrm{w}$ tego typu wypadkach zasądzać zwrot świad-

12 G. B. Burke, The Proper Law of a Contract for the Sale of Goods, Arbitration 1924, Oct, s. 6-7. Zauważmy, że również na prawo angielskie wskazałyby polskie regulacje, gdyby sprawa zawisła przed polskim sądem: art. 8 pkt 3 względnie art. 9 ust. 1 ustawy z dnia 2 sierpnia 1926 r. o prawie właściwem dla stosunków prywatnych międzynarodowych, a współcześnie art. 4 ust. 1 rozporządzenia Parlamentu Europejskiego i Rady (WE) nr 593/2008 z dnia 17 czerwca 2008 r. w sprawie prawa właściwego dla zobowiązań umownych (Rzym I) z dnia 17 czerwca 2008 r.

13 Na marginesie można zauważyć, że w gruncie rzeczy nie wiemy, kto rzeczywiście był zainteresowany ekonomicznie wynikiem omawianego procesu - Fibrosa czy może już tylko jej brytyjscy agenci? 
czenia (zaliczki), a to wobec wystąpienia całkowitego upadku przyczyny, dla której świadczono (total failure of consideration).

W istocie precedens z 1904 r. już wcześniej traktowano jako kontrowersyjny ${ }^{14}$. Lordowie Dunedin i Shaw poddali go krytyce w wyroku Cantiare San Rocco S.A. v. Clyde Shipbuilding and Engineering Co. Ltd. (1924) ${ }^{15}$. Stany faktyczne spraw rozstrzyganych w latach $1924 \mathrm{r}$. i $1942 \mathrm{r}$. były do siebie podobne. Chociaż w obu orzekała Izba Lordów, to w tej pierwszej zastosowanie znalazło prawo szkockie, a nie angielskie. Dlatego sceptyczne wypowiedzi lordów co do prawidłowości Chandler v. Webster (1904) miały wyłącznie charakter obiter dictum. Mimo to prawnicy Fibrosy wielokrotnie powoływali się na wyrok z 1924 r. Proces dotyczył zwrotu zaliczki uiszczonej na poczet zapłaty za silniki okrętowe dla firmy z Triestu (wówczas Austro-Węgry), które miały zostać wykonane przez stocznię w Glasgow. Wybuch I wojny światowej uniemożliwił realizację umowy. Sąd niższej instancji oddalił roszczenie właśnie opierając się na precedensie Chandler v. Webster (1904). Na skutek apelacji lordowie przyjęli, że $\mathrm{w}$ razie wygaśnięcia umowy należał się zwrot zaliczki, a to z uwagi na upadek przyczyny dla której świadczono ${ }^{16}$. Podstawą rozstrzygnięcia była znana prawu szkockiemu romanistyczna ${ }^{17}$ zasada restytucji (bezpodstawnego wzbogacenia), a nie obowiązująca w Anglii konkurencyjna koncepcja opierająca roszczenia na dorozumianym konsensusie stron (podstawa kontraktowa $)^{18}$.

14 Krytykiem Chandler v. Webster (1904) był również lord Atkin - jeden z sędziów orzekających w 1942 r., por. jego obiter dictum w Russkoe Obschestvo d'lia Izgstovlenia Snariadov l'voennick Pripassov v. John Stirk \& Sons (1922), Ld. 10 Ll.L.Rep.214 (za: Fibrosa S.A., (1943) A.C. 45).

15 Cantiare San Rocco S.A. v. Clyde Shipbuilding and Engineering Co. Ltd. (1924) A.C. 247 (lord Dunedin), 257-259 (lord Shaw). Wskazuje się, że posłużenie sie argumentacją nawiązującą do tradycji rzymskiej było przyczyną, dla której w kolejnych latach angielskie sądy nie powoływały się na wyrok z 1924 r. (R. Evans-Jones, Roman Law in Scotland and England and the Developement of one Law for Britain, "The Law Quarterly Review" 1999, nr 15, s. 616-617; Ł. Marzec, Sprawa Fibrosa vs Fairbairn. Polska spótka, Izba Lordów i prawo rzymskie, „Zeszyty Prawnicze UKSW" 2007, nr 7/1, s. 120). Wydaje się, że rzeczywistym powodem braku zainteresowania z ich strony był fakt, że Izba Lordów orzekała opierając się na prawie szkockim, zatem wypowiedzi sędziów miały charakter obiter dictum.

16 Lordowie Birkenhead (234, 238), Dunedin (246) i Shaw (251) błędnie wskazywali condictio causa data causa non secuta jako podstawę rozstrzygnięcia. W nauce podaje się, że właściwym rzymskim odpowiednikiem winna być - słusznie - condictio causa finita (R. Evans-Jones, Roman Law in Britain, s. 91-92; J. Halberda, Historia zobowiqazan quasi-kontraktowych w common law, Kraków 2012, s. 337-338; Ł. Marzec, op. cit., s. 117-118) lub akcja kontraktowa oparta na zasadzie dobrej wiary (P. Mitchell, op. cit., s. 259).

17 Na rzymskie korzenie prawa szkockiego wskazywali lordowie Birkenhead (234), Dunedin (244) i Shaw (250-252).

18 Cantiare San Rocco S.A. v. Clyde Shipbuilding and Engineering Co. Ltd. (1924) A.C. 226, Fibrosa S.A., (1943) A.C. 36. R. Evans-Jones, Roman Law in Scotland..., s. 607-610; idem, Roman Law in Britain, s. 86-89; P. Mitchell, op. cit., s. 258-259. 
Coronation cases nie znalazły uznania również w oczach kodyfikatorów działających po obu stronach Atlantyku. American Law Institute doprowadził do wydania Restatement of Contracts (1932), opracowania prezentującego ówczesny stan amerykańskiego prawa zobowiązań kontraktowych. Autorzy zbioru byli sceptyczni względem prawidłowości rozstrzygnięć w procesach koronacyjnych, na co zwracał uwagę lord Wright orzekający w omawianym procesie z 1942 r. Na amerykańskie Restatement, tym razem Restatement of Restitution (1937), powoływali się - krytykujący ówczesny stan common law - sędziowie w innej współczesnej sprawie United Australia v. Barclays Bank (1941) ${ }^{19}$. Lord Wright sam zasiadał w brytyjskiej komisji kodyfikacyjnej (Law Revision Committee). Stworzone przez nią rekomendacje (1939) sugerowały po pierwsze, przyjęcie jako zasady zwrotu świadczeń na rzecz wierzyciela (powoda) w razie wygaśnięcia umowy na skutek frustration, a po drugie, możliwość uwzględnienia - według sędziowskiego uznania - wydatków poniesionych przez dłużnika (pozwanego) w toku realizacji takiej umowy. Dalsze prace legislacyjne przerwał wybuch wojny ${ }^{20}$.

Prawnicy Fibrosy musieli brać pod uwagę ryzyko, że argumentacja skierowana przeciwko precedensowi z 1904 r. okaże się bezskuteczna. Właśnie dlatego - wraz z żądaniem zwrotu zadatku - domagali się zapłaty odszkodowania za niewykonanie umowy oraz nakazania jej wykonania. W tym zakresie podnosili, iż do wygaśnięcia umowy na skutek frustration w ogóle nie doszło $\mathrm{z}$ uwagi na regulacje paragrafu 7 umowy. To postanowienie przewidywało zmiany harmonogramu dostawy, gdyby z przyczyn niezależnych od stron, $\mathrm{w}$ tym $\mathrm{w}$ szczególności $\mathrm{w}$ razie strajku, wojny, pożaru, wykonanie umowy $\mathrm{w}$ terminie okazało się utrudnione. Sądy - zgodnie ze stanowiskiem pozwanych - uznały jednak, że paragraf 7 odnosić się mógł wyłącznie do przejściowego konfliktu, a nie długotrwałej wojny ${ }^{21}$.

\section{c) Argumenty Fairbairn}

Prawnicy pozwanego koncentrowali się wokół wykazania zasadności utrzymania przez Izbę Lordów dotychczasowych precedensów, przede wszystkim Chandler v. Webster (1904). W kontekście funkcjonowania zasady precedensu warto wskazać, że procesy koronacyjne zostały rozstrzygnięte przez

19 United Australia v. Barclays Bank (1941) A.C. 1, 18 (Viscount Simon L.C.), 26 (lord Atkin), Fibrosa S.A., (1943) A.C. 71 (lord Wright). Wskazuje się, że amerykańskie Restatement wywarło wpływ na późniejszy rozwój prawa w krajach common law - m.in. w Anglii (S. Hedley, Restitution in English Common Law, [w:] The Oxford International Encyclopedia of Legal History, red. S.N. Katz, t. V, Oxford 2009, s. 130), w Kanadzie (M. McInnes, The Reason to Reverse: Unjust Factors and Juristic Reasons, "Boston University Law Review" 2012, nr 92, s. 1049-1052).

21 Fibrosa S.A., (1943) A.C. 40-41 (Viscount Simon L.C.). P. Mitchell, op. cit., s. 267-268. 
Sąd Apelacyjny, zaś w Fibrosie orzekała Izba Lordów. Wyroki sądu niższego nie wiązały formalnie sądu wyższego, a wobec tego podczas gdy Sąd Apelacyjny w procesie Fibrosa był związany precedensem z 1904 r., Izba Lordów - nie ${ }^{22}$. Mimo to prawnicy pozwanego wskazywali, że Chandler v. Webster (1904) został zaaprobowany przez Izbę Lordów w jednym $\mathrm{z}$ jej orzeczeń z $1921 \mathrm{r}$. Ta argumentacja nie zyskała jednak uznania. Lordowie Atkin i Wright wyjaśnili, że ów wyrok z 1921 r. odnosił się do innego stanu faktycznego (zapłaty frachtu, który w myśl morskiego zwyczaju handlowego nie podlegał zwrotowi), a nadto wobec sprzecznych opinii orzekających lordów ratio decidendi tego wyroku nie było jasne i przez to nie mógł zyskać mocy precedensu ${ }^{23}$.

Prawnicy pozwanego wskazywali nadto - jak się przekonamy: nieskutecznie - że w sprawie nie zachodzi wypadek total failure of consideration, a to $\mathrm{z}$ uwagi na fakt, że $\mathrm{w}$ pewnej części umowa została już wykonana przez pozwanego. Wprawdzie doszło do upadku przyczyny, dla której świadczono, ale upadek ten miał charakter częściowy, a nie zupełny, całkowity (total). Chociaż maszyny nie zostały dostarczone do Polski, to jednak Fairbairn spacjalnie je dla Fibrosy wyprodukował. Chociaż powód z zawartej umowy nie uzyskał do tej pory nic, to $\mathrm{z}$ perspektywy pozwanego $\mathrm{w}$ znaczącym zakresie prace zostały wykonane ${ }^{24}$.

\section{Wyrok Izby Lordów}

Izba Lordów wyrokiem z 15 czerwca 1942 r. uwzględniła apelację Fibrosy w zakresie zwrotu zaliczki. Głównym sprawozdawcą, autorem leading speach, był Viscount Simon L.C. Po gruntownej analizie orzecznictwa, lordowie uznali, że skoro doszło do zupełnego upadku przyczyny, dla której świadczono (total failure of consideration), to mimo wygaśnięcia umowy na skutek niemożliwości wykonania (frustration), świadczenie powinno zostać zwrócone.

W rezultacie uchylono wyrok i przekazano sprawę do rozstrzygnięcia w niższej instancji, gdzie jednak - zdaniem Paula Mitchella - nie prowadzono już dalszego postępowania. Zdaniem tego autora wyrok Izby Lordów nie miał

\footnotetext{
22 Wskazując na fakt związania precedensem Sąd Apelacyjny wyrażał nadzieję, że być może Izba Lordów przyjmie „more civilised rule" rozstrzygając spór Fibrosy z Fairnbarn (za: Fibrosa S.A., (1943) A.C. 45). Gdyby coronation cases były wyrokami Izby Lordów, to najpewniej stwierdzono by, że również ona nie może orzec inaczej niż w 1904 r. Od zasady niepodważalności (własnego) precedensu wyrażonej w London Street Tramways v. London City Council (1898) A.C. 375, 379 odstąpiono dopiero mocą deklaracji Izby Lordów z 1966 r. (Practical Statement, 3 All E.R. 77).

23 French Marine v. Compagnie Neapolitaine d'Eclairage et de Chauffage par le Gas (1921) 2 A.C. 494 Fibrosa S.A., (1943) A.C. 54 (lord Atkin), 71 (lord Wright).

24 Fibrosa S.A., (1943) A.C. 38-39.
} 
żadnego znaczenia praktycznego ponieważ ustawa z 1939 r. zakazując dokonywania płatności na rzecz wrogów Korony uniemożliwiała wykonanie orzeczenia. Właśnie dlatego Fibrosa miała zaniechać prowadzenia dalszych działań po wydaniu wyroku przez Izbę Lordów ${ }^{25}$. Trudno zaakceptować powyższe wnioskowanie. Fibrosa uzyskała wszak zezwolenie na prowadzenie postępowania, a to $\mathrm{w}$ konsekwencji powinno umożliwiać jej również wyegzekwowanie wydanego orzeczenia. W przeciwnym razie wydawanie zgód przez Ministerstwo Handlu pozbawione byłoby sensu ${ }^{26}$. Można postawić tezę, że brak dalszych kroków sądowych Fibrosy spowodowany był po prostu dokonaniem przez Fairbairn zwrotu zaliczki.

\section{a) Pozbawienie mocy precedensu z $1904 \mathrm{r}$.}

Izba Lordów poddała gruntownej krytyce rozstrzygnięcia zapadłe na kanwie procesów koronacyjnych. W myśl Chandler v. Webster (1904) wystąpienie frustration wyłączało a limine możliwość zastosowania konstrukcji total failure of consideration. Lordowie odstąpili od tego poglądu. Nie oznaczało to jednak zwrotu świadczenia w każdym wypadku. W razie wygaśnięcia umowy należało bowiem stwierdzić, czy spełniły się rygorystyczne przesłanki zastosowania total failure of consideration. W tej mierze - zgodnie z utrwaloną linią orzeczniczą - lordowie podnosili, iż nie wystarczy by nastąpił upadek przyczyny, dla której świadczono, ale by owa przyczyna upadła w sposób zupełny (total), a nie wyłącznie częściowy ${ }^{27}$.

Z drugiej jednak strony wskazywali, że zawężenie przez sędziego Collinsa M.R. (w 1904 r.) sfery zastosowania total failure of consideration do wypadków nieważności umowy ab initio i wyłączenie z niej sytuacji następczej niemożliwości świadczenia było błędne ${ }^{28}$. Podnosili, że źródłem tej pomyłki były po pierwsze brak rozróżnienia dwóch znaczeń pojęcia consideration - kontraktowego (odpowiednik causa debendi) i restytucyjnego (świadczenie) ${ }^{29}$, a po drugie, niewłaściwe nawiązanie do rozstrzygnięć Taylor v. Caldwell (1863) i Appleby v. Myers (1867) dotyczących zupełnie innych roszczeń - o wykonanie

25 P. Mitchell, op. cit., s. 273. part of the consideration he can get no compensation"), 56 (lord Russell), 60-61 (lord MacMillan), 72 (lord Wright), 73-75 (lord Roche), 77 (lord Porter).

28 Roche).

29 as the failure of consideration, but the performance of the promise"), 60 (lord MacMillan), 68-69 (lord Wright). F. Wilmot-Smith, Reconsidering „total" failure, “Cambridge Law Journal” 2013, nr 72, s. 423. 
lub odszkodowanie - a nie o zwrot świadczenia ${ }^{30}$. W ten sposób Chandler v. Webster (1904) został pozbawiony mocy precedensu (overruled) ${ }^{31}$.

\section{b) Argumenty cywilistyczne}

Rozstrzygając spór Fibrosy z Fairnbarn lordowie kilkakrotnie podkreślali, że ukształtowane mocą precedensu z 1904 r. prawo angielskie - inaczej niż rzymskie czy szkockie - nie pozwala uwzględnić roszczenia o zwrot zaliczki. W nauce wskazuje się wobec tego, że decyzja Izby Lordów z 1942 r. stanowi przykład recepcji rozwiązań szkockich i pośrednio rzymskich ${ }^{32}$. Wydaje się, że sami lordowie - skonfrontowani z powyższą tezą - byliby poważnie zaskoczeni, zaś pozbawienie Chandler v. Webster (1904) mocy precedensu w omawianym wyroku to kolejny etap organicznego rozwoju common law.

Nawiązywanie do prawa rzymskiego i szkockiego - chociaż zwłaszcza co do tego pierwszego stanowi rzeczywiście w Anglii rzadkość - nie powinno nas w tym konkretnym wypadku dziwić. Orzekając w sprawie Fibrosy lordowie musieli odnieść się do wyroku Cantiare San Rocco S.A. v. Clyde Shipbuilding and Engineering Co. Ltd. (1924) dotyczącego niemal identycznego stanu faktycznego. $W$ tej zaś sprawie podstawą rozstrzygania było właśnie prawo szkockie, które $\mathrm{w}$ tej mierze opierało się z kolei na prawie rzymskim.

Analizując skutki stosowania prawa angielskiego i szkockiego w sytuacjach następczej niemożliwości świadczenia (frustration), sędziowie dochodzili do sprzecznych konkluzji. Podczas gdy lord Atkin wyrażał zadowolenie z powodu zbliżenia się obu porządków prawnych w tym zakresie, lordowie Russell i Roche akcentowali istniejące różnice. Wskazywali, że na gruncie prawa szkockiego roszczenie o zwrot świadczenia powinno zostać uwzględnione, zaś w razie zastosowania prawa angielskiego - oddalone. Wydaje się, że rozwiązaniem tego paradoksu jest uznanie, że ci ostatni odnosili się do stanu prawnego wynikającego z precedensu Chandler v. Webster (1904), zaś lord Atkin uwzględniał już utratę przezeń mocy na skutek overruling dokonywanego mocą wyroku w sprawie Fibrosy. Wypowiedzi lordów co do prawa szkockiego i rzymskiego formułowane były jako obiter dicta i nie miały wpływu na wynik sporu. Lord

30 Taylor v. Caldwell (1863) 3 B. \& S. 826 (za: A. Burrows, op. cit., s. 674-675), Appleby v. Myers (1867) L.R. 2 C.P. 651 (za: G. McMeel, op. cit., s. 249-250), Fibrosa S.A., (1943) A.C. 45 (Viscount Simon L.C.), 52 (lord Atkin), 68-69 (lord Wrigjt), 80-81 (lord Porter).

31 Fibrosa S.A., (1943) A.C. 44-45, 49 (Viscount Simon L.C.). Na skutek w postaci overruling wskazuje się w judykaturze: Great Peace Shipping Ltd v. Tsavliris Salvage (International) Ltd (2002) EWCA Civ 1407, (2003) Q.B. 702-703 (lord Phillips of Worth Matravers M.R.), Toovey \& Anor, R (on the application of) v. Law Society (2002) EWHC 391 (Burnton J., pkt 71), Cadogan Petroleum Holdings Ltd v. Global Process Systems LLC (2013) 1 C.L.C. 733-734 (Eder J.). R. Goff, G. Jones, The Law of Restitution, London 2002, s. 498; P. Mitchell, op. cit., s. 271.

32 Ł. J. Korporowicz, Prawo rzymskie w wybranych orzeczeniach Izby Lordów w latach 1999-2009, Z dziejów prawa, t. 4 (12), Katowice 2011, s. 283-284; Ł. Marzec, op. cit., s. 113-114, 120. 
Russell wskazywał, że orzekając w sprawie nie można brać pod uwagę prawa szkockiego czy rzymskiego, a jedynie angielskie. Lord Wright zaznaczał, że oba prawa (angielskie i szkockie) przewidują zwrot świadczenia pieniężnego (z wyłączeniem niepieniężnego) w razie upadku przyczyny, z uwagi na którą zostało ono spełnione. Lord Porter dodawał, w Szkocji, inaczej niż w Anglii, nie wymaga się, by upadek przyczyny miał charakter zupełny. $Z$ kolei lord Roche zauważał, że umożliwiając miarkowanie restytucji prawo cywilne (rzymskie) i prawo szkockie pozwala - w większym stopniu niż ma to miejsce na gruncie prawa angielskiego - sprawiedliwie rozstrzygać spory w sprawach total failure of consideration ${ }^{33}$. Wydaje się, że sędzia pozostawał w błędzie. Chociaż podobnie jak on lordowie Birkenhead (w Cantiare San Rocco S.A., 1924) i Atkin (w 1942 r.) wskazywali na miarkowanie odpowiedzialności pozwanego $\mathrm{w}$ prawie rzymskim, to współczesna nauka romanistyczna prezentuje odmienne stanowisko ${ }^{34}$. Podobnie co do prawa szkockiego - podczas gdy lord Shaw (1924) stwierdził dopuszczalność uwzględnienia wydatków poniesionych przez pozwanego, to lord Atkin (1942) uznał wypowiedź swego poprzednika za błędnąą.

Zauważmy, że odniesienia do prawa rzymskiego czy szkockiego nie miały wpływu na rozstrzygnięcie sprawy Fibrosy - proces dotyczył wszak zaliczki (zatem pieniędzy), zaś upadek przyczyny, dla której świadczono miał - zdaniem sędziów - charakter zupełny. W tym zakresie prawa szkockie i angielskie nie różniły się między sobą. Z pewnością o wpływie prawa szkockiego można by mówić w wypadku zasądzenia zwrotu mimo stwierdzenia, że chociaż upadek przyczyny nastąpił, to był jedynie częściowy.

Poza nawiązaniami do prawa szkockiego i rzymskiego występują także odwołania do prawa natury. W tym kontekście lord MacMillan cytował Samuela Puffendorfa prezentującego słusznościową zasadę umożliwiającą uwzględnienie interesów stron stosunku restytucyjnego. Wskazywał przy tym, że prawo angielskie nie przyjęło jak dotąd tej zasady ${ }^{36}$. Zauważmy, że wyrok w sprawie Fibrosy nie doprowadził $\mathrm{w}$ tym zakresie do żadnej zmiany.

\section{c) Podstawa roszczenia}

Lordowie znacznie różnili się między sobą co do uzasadnienia wyroku. Viscount Simon L.C. akcentował konieczność skrupulatnej analizy stworzo-

33 Fibrosa S.A., (1943) A.C. 54 (lord Atkin), 55 (lord Russell), 71 (lord Wright), 74, 76 (lord Roche), 77 (lord Porter).

34 W. Litewski, Stownik encyklopedyczny prawa rzymskiego, Kraków 1998, s. 52; M. Sobczyk, Zamierzony cel świadczenia nie został osiagnięty (condictio ob rem). Przykład przydatności myśli jurystów rzymskich dla wykładni przepisów kodeksu cywilnego, „Kwartalnik Prawa Prywatnego” 2004, nr 4, s. 1013.

35 Cantiare San Rocco S.A. v. Clyde Shipbuilding and Engineering Co. Ltd. (1924) A.C. 227, 235 (lord Birkenhead), 259-260 (lord Shaw), Fibrosa S.A., (1943) A.C. 54 (lord Atkin).

36 Fibrosa S.A., (1943) A.C. 58-59 (lord MacMillan). 
nej przez strony umowy. W pierwszej kolejności to właśnie $\mathrm{w}$ jej treści należało odnaleźć regulację skutków frustration. Dopiero w razie braku stosownych postanowień sąd winien określić konsekwencje wygaśnięcia umowy poprzez implikację fikcyjnego porozumienia między stronami. Z tej właśnie przyczyny należało ocenić jaki charakter miało spełnione przez jedną ze stron świadczenie: czy zaliczka miała cechy zapłaty warunkowej czy ostatecznej, definitywnej ${ }^{37}$.

Niezwykle postępowe stanowisko prezentował lord Wright. Jego zdaniem podstawą rozstrzygnięcia powinna być - do tej pory nie uwzględniana przez angielskie common law - zasada bezpodstawnego wzbogacenia. Wypowiedzi tego sędziego stanowią najczęściej cytowany fragment tego wyroku. Lord Wright kładł nacisk na konieczność uwzględnienia przez każdy rozwinięty system prawny obok roszczeń kontraktowych i deliktowych również tych zmierzających do zwrotu bezpodstawnego wzbogacenia ${ }^{38}$. To właśnie stwierdzenie decyduje o znaczeniu kazusu Fibrosy dla późniejszego rozwoju angielskiego law of restitution.

Do tej pory angielskie prawo zobowiązań z uwagi na historyczne zaszłości - oparcie ewolucji na średniowiecznym systemie rytów procesowych - zorganizowane było dychotomicznie. Wyróżniano wyłącznie roszczenia kontraktowe oraz deliktowe. Sytuacje, w których na Kontynencie dostrzeżono by kazus bezpodstawnego wzbogacenia, traktowano w Anglii jako uruchamiające roszczenie quasi-kontraktowe. I tak, w wypadkach nienależnego świadczenia, spełnionego na przykład pod wpływem błędu (mistake), roszczenie o jego zwrot przysługiwało solvensowi, o ile dało się skonstruować dorozumiany kontakt (implied contract), wedle którego accipiens miał zwrócić solvensowi dokonaną zapłatę (money had and received).

Lord Wright - nawiązując do wypowiedzi lorda Mansfielda wygłoszonych na kanwie procesu Moses v. MacFerlan (1760) ${ }^{39}$ - twierdził, że powyższe roszczenia powinny być wywodzone z zasady bezpodstawnego wzbogacenia, a nie $\mathrm{z}$ implikowanej obietnicy pozwanego lub porozumienia między stronami. Położenie akcentu na bezpodstawności wzbogacenia oznaczało odejście od reżimu kontraktowego. Zdaniem tego sędziego bezpodstawne wzbogacenie powinno

37 Fibrosa S.A., (1943) A.C. 42, 46 (Viscount Simon L.C.), 67 (lord Wright), 74 (lord Roche), 77, 83 (lord Porter).

38 Fibrosa S.A., (1943) A.C. 61 (lord Wright): „It is clear that any civilized system of law is bound to provide remedies for cases of what has been called unjust enrichment or unjust benefit, that is to prevent a man from retaining the money of or some benefit derived from another which it is against conscience that he should keep. Such remedies in English law are generically different from remedies in contract or in tort, and are now recognized to fall within a third category of the common law which has been called quasi-contract or restitution."

Moses v. MacFerlan (1760) 2 Burrow 1005 (za: G. McMeel, op. cit., s. 4 i nast.). 
stanowić osobny filar prawa zobowiązań ${ }^{40}$. Co istotne, formułując swoje stanowisko lord Wright odwoływał się do dawnego, osiemnastowiecznego dorobku orzeczniczego lorda Mansfielda. Występujące w treści uzasadnienia wyroku nawiązania do tradycji romanistycznej i do prawa szkockiego odnosiły się do innych - opisanych wyżej - zagadnień. Wydaje się zatem, że prawo rzymskie i prawo szkockie $\mathrm{w}$ istocie rzeczy nie miały bezpośredniego ${ }^{41}$ wpływu na treść rozstrzygnięcia zapadłego w $1942 \mathrm{r}$.

\section{Krytyka wyroku}

Uzasadniając wyrok w procesie Fibrosy, lordowie wskazali na szereg niedoskonałości common law.

\section{a) Brak miarkowania odpowiedzialności}

Przede wszystkim sędziowie zwracali uwagę na brak mechanizmów umożliwiających uwzględnienie wydatków pozwanego. Common law nie pozwalało zatem na miarkowanie zakresu jego odpowiedzialności, co miało szczególnie istotne znaczenie $\mathrm{w}$ przypadku poniesienia przez pozwanego kosztów na potrzeby realizacji umowy. Omawiany problem miał wymiar praktyczny. Takie bowiem wydatki faktycznie zostały poniesione przez Fairbairn: pozwani wyprodukowali specjalnie dla konkretnego klienta - Fibrosy - zamówione maszyny, które nie były towarem dającym się łatwo sprzedać. Jak wynika z uzasadnienia wyroku, przedsiębiorcom z Leeds udało się sprzedać maszyny, a dzięki temu nakłady na ich produkcję zostały pokryte. Gdyby maszyn nie sprzedano, to pozwany nie dysponowałby żadnym zarzutem umożliwiającym obniżenie kwoty przeznaczonej do zwrotu.

Mimo stwierdzenia luk w common law lordowie orzekający w sprawie Fibrosy nie zdecydowali się na zmiany w tym obszarze. Podnosili, że te powinny zostać wprowadzone przez legislację. Powstrzymanie się przez Izbę Lordów od zmiany prawa $\mathrm{w}$ powyższym zakresie poddane zostało krytyce, zwłaszcza w nauce ${ }^{42}$.

40 Fibrosa S.A., (1943) A.C. 61-63 (lord Wright); N. Duxbury, Lord Wright and Innovative Traditionalism, "University of Toronto Law Journal" 2009, nr 59, s. 309-311, 316, 318. Atak na doktrynę quasi-kontraktów został zainicjowany przez lorda Wrighta we wcześniejszej sprawie Brook's Wharf and Bull Wharf, Ltd. v. Goodman Bros.(1937) 1 K.B. 534 oraz przez lorda Atkina w United Australia v. Barclays Bank (1941) A.C. 1, 28-29.

41 Pewien wpływ tradycja cywilistyczna mogła mieć natomiast na rozstrzygnięcia lorda Mansfielda, $\mathrm{w}$ tym i to $\mathrm{z} 1760 \mathrm{r}$.

42 Fibrosa S.A., (1943) A.C. 49-50 (Viscount Simon L.C.), 72 (lord Wright), 76 (lord Roche), 78 (lord Porter). A. Burrows, op. cit., s. 698; R. Evans-Jones, Roman Law in Britain, s. 92-93; P. Mitchell, op. cit., s. 275-276. 
Angielskie common law nie brało również pod uwagę innych możliwych zmian $\mathrm{w}$ majątku pozwanego, które - związane z otrzymanym od powoda świadczeniem - mogły doprowadzić do pozbawienia go wzbogacenia na moment orzekania w sprawie. Nie znano zatem zasady ograniczenia odpowiedzialności do wysokości aktualnego wzbogacenia pozwanego współcześnie realizowanej przez zarzut zmiany położenia (change of position defence $)^{43}$.

\section{b) Rodzaj świadczenia}

$\mathrm{Na}$ inną z wad prawa angielskiego, która jednakże nie miała wpływu na treść rozstrzygnięcia w omawianej sprawie, zwrócił uwagę lord Wright. Fibrosa dochodziła w procesie zwrotu zaliczki, a zatem świadczenia pieniężnego. Tymczasem common law nawet $\mathrm{w}$ ograniczonym zakresie nie obejmowało ochroną prawną kontrahenta, który przed wystąpieniem frustration spełnił świadczenie niepieniężne. Zdarzało się, że powyższe prowadziło do niesprawiedliwych i trudnych do zaakceptowania konsekwencji, czego ilustracją może być wyrok Appleby v. Myers (1867). W tej sprawie powód zobowiązał się do wykonania na nieruchomości pozwanego prac budowlanych. $W$ toku prac wzniesione przez niego instalacje zostały uszkodzone przez ogień. Wobec niemożliwości kontynuowania robót budowlanych umowa wygasła, zaś żądanie zapłaty za wykonaną część prac zostało oddalone ${ }^{44}$.

\section{c) Zupełność upadku przyczyny, dla której świadczono}

W komentowanym orzeczeniu lordowie niemal jednogłośnie potwierdzili, że zasądzenie zwrotu świadczenia było warunkowane wystąpieniem total failure of consideration ${ }^{45}$. W związku z tym, jeśli upadek przyczyny, dla której świadczono nie był zupełny, a wyłącznie częściowy, to - niezależnie od innych okoliczności - świadczenie nie podlegało zwrotowi. Ta, ugruntowana już w XVIII w., zasada prowadziła bardzo często do krzywdzących rozstrzygnięć. Często posługiwano się kazusem Whincup v. Hughes (1871), by zobrazować jej niesprawiedliwość. W tej sprawie powód oddał swego syna na sześć lat na praktykę do zegarmistrza, za co był zmuszony zapłacić z góry. Tak się złożyło,

43 Lipkin Gorman v. Karpnale Ltd (1991) 2 A.C. 548 (zob. także: G. McMeel, op. cit., s. 416-418, 493-497, 516-520). Na gruncie prawa polskiego zasada odpowiedzialności w granicach aktualnego wzbogacenia wynikała z art. $127 \mathrm{w}$ zw. z art. 133 §1 kodeksu zobowiązań, a aktualnie - z art. 409 kodeksu cywilnego.

44 Appleby v. Myers (1867) L.R. 2 C.P. 651 (za: G. McMeel, op. cit., s. 249-250), Fibrosa S.A., (1943) A.C. 71 (lord Wright). A. Burrows, op. cit., s. 698, P. Mitchell, op. cit., s. 275.

45 Fibrosa S.A., (1943) A.C. 46 (Viscount Simon L.C.), 55 (lord Atkin), 56 (lord Russell), 60-61 (lord MacMillan), 72 (lord Wright), 73-75 (lord Roche), 77 (lord Porter). 
że mistrz zmarł przed upływem pierwszego roku obowiązywania kontraktu. Kiedy powód wystąpił o zwrot świadczenia, roszczenie oddalono, wskazując, iż upadek przyczyny, jaki zachodzi w tej sprawie, nie nosi cechy zupełności ${ }^{46}$. Spośród sędziów orzekających w 1942 r. jedynie lord Wright konsekwentnie krytykował ograniczenie restytucji do wypadków zupełnego upadku przyczyny. Jego zdaniem - chociaż należy uznać te uwagi za postulaty de lege ferenda - restytucja powinna być możliwa również $\mathrm{w}$ razie częściowego upadku przyczyny ${ }^{47}$.

Na marginesie należy stwierdzić, że kwalifikacja kazusu Fibrosy jako wypadku total failure of consideration jest kontrowersyjna. Chociaż wileńska spółka nie otrzymała maszyn, to jednak Fairbairn w części wykonała umowę - przedmiotowe maszyny zostały przecież wyprodukowane. Podobne zagadnienia rozważano w innej „polskiej” sprawie Stocznia Gdańska S.A. v. Latvian Shipping Co. and Others (1998). Polska spółka domagała się zapłaty jednej z rat za budowane w Gdańsku chłodniowce (statki-chłodnie). Umowa na ich budowę została rozwiązana wobec braku zapłaty drugiej raty. Statki zostały dokończone i sprzedane - jednak za niższą cenę - innym armatorom. Pozwani domagali się oddalenia powództwa twierdząc, że skoro nie otrzymali statków, to spełniły się przesłanki total failure of consideration. Powołując się na wyrok $\mathrm{w}$ sprawie Fibrosa żądali zwrotu pierwszej raty. Mimo to Stocznia Gdańska wygrała proces. Lordowie dokonali rozróżnienia obu kazusów wskazując, że w 1942 r. chodziło wyłącznie o sprzedaż maszyn, zaś w 1998 r. o wybudowanie stat$\mathrm{kó}^{48}$. To rozróżnienie wydaje się błędne, bo stany faktyczne obu spraw były bardzo podobne. Zauważmy, że w wyroku Fibrosy stwierdzono total failure of consideration analizując sprawę od strony kupującego, który istotnie nic nie otrzymał, zaś w sprawie Stoczni posłużono się perspektywą sprzedającego, zaś ten $\mathrm{w}$ części wykonał zadanie. Wydaje się, że to nowsze spojrzenie jest właściwe. Kontrakt z 1939 r. nie dotyczył wyłącznie sprzedaży, ale wytworzenia i montażu maszyn. Zatem skoro Fairbairn w części wykonał umowę, to nie można było uznać, że spełniły się przesłanki zupełnego upadku przyczyny, dla której świadczono. Zapewne błąd w ustaleniu faktów w 1942 r. spowodowany

46 Whincup v. Hughes (1871) L.R. 6 C.P. 78 (za: G. McMeel, op. cit., s. 250-251). A. Burrows, op. cit., s. 698.

47 Fibrosa S.A., (1943) A.C. 64-65 (lord Wright: „where the consideration, if entire, has entirely failed, or where, if it is severable, it has entirely failed as to the severable residue."). Posługiwał się sformułowaniem „failure of consideration" lub podobnymi, a zatem bez wyrazu "total" (s. 61, 64, 65, 67, 69). Wskazywał (s. 71), że w sprawie French Marine v. Compagnie Neapolitaine d'Eclairage et de Chauffage par le Gas (1921) 2 A.C. 494, zasądzono roszczenie, chociaż upadek przyczyny miał charakter cząstkowy. Mimo to, biorąc pod uwagę część jego wypowiedzi na stronie 72 report, należy przyjąć, że de lege lata uznawał konieczność całkowitego upadku przyczyny jako przesłanki zwrotu świadczenia.

48 Stocznia Gdańska S.A. v. Latvian Shipping Co. Latreefer Inc. and Others (1998) 1 Lloyd's Rep. 609. F. Wilmot-Smith, op. cit., s. 417. 
był tym, że lordowie próbowali doprowadzić do sprawiedliwego rozstrzygnięcia sporu, zaś uznanie, że upadek przyczyny nie nosi cechy zupełności mógł te plany pokrzyżować.

\section{d) Wykładnia umowy}

Paul Mitchell zwracał uwagę na jeszcze inną wadę omawianego wyroku: błędną wykładnię postanowień umowy. Zdaniem tego autora okoliczności zawarcia kontraktu wskazywały, że będąca przedmiotem procesu zaliczka miała charakter świadczenia bezzwrotnego, a wobec tego nawet $\mathrm{w}$ razie wygaśnięcia umowy nie powinna podlegać restytucji. Wspomniane okoliczności to przede wszystkim data zawarcia kontraktu. W lipcu 1939 r. było już wiadomo, że wojna w Polsce jest niemal pewna. Standardowe warunki sprzedaży Fairbairn przewidywały zapłatę za towar dopiero po dokonaniu dostawy, podczas gdy z Fibrosą uzgodniono inne zasady rozliczenia. $W$ tym kontekście autor odmiennie niż lordowie zinterpretował warunki kontraktu dochodząc do wniosku, że uzgodniona kwota zaliczki (1.600 funtów) miała charakter zapłaty bezzwrotnej ograniczającej ryzyko nieotrzymania zapłaty za wykonane prace wobec wybuchu wojny ${ }^{49}$.

\section{Reforma z 1943 r.}

Pod wpływem omawianego orzeczenia przyspieszono prace legislacyjne nad ustawą mającą usunąć dostrzeżone luki prawne. W kolejnym roku wydano Law Reform (Frustrated Contracts) Act (1943). Przedmiotem regulacji tej ustawy były konsekwencje wygaśnięcia umowy na skutek niezawinionej przez żadną ze stron niemożliwości jego wykonania.

Po pierwsze, umożliwiono dochodzenie zwrotu świadczenia również $\mathrm{w}$ innych wypadkach niż zupełny upadek przyczyny, dla której świadczono (total failure of consideration). Odtąd restytucja miała być możliwa także wtedy, gdy przyjmujący świadczenie w pewnym zakresie wykonał swoją część umowy (sekcja 1(2)). Zauważmy, że przedstawiona regulacja statutowa miała charakter lex specialis względem common law, a skoro tak to odnosiła się wyłącznie do kazusów frustration, z wyłączeniem innych wypadków upadku przyczyny dla której świadczono. W tych drugich wciąż wymagano, by ów upadek miał charakter zupełny (total failure of consideration). W ostatnich latach nauka i orzecznictwo wskazują na potrzebę rozważenia czy przesłanka zupełności jest konieczna ${ }^{50}$.

49 P. Mitchell, op. cit., s. 273-4.

50 R. Goff, G. Jones, op. cit., s. 497-499; F. Wilmot-Smith, op. cit., s. 414 i nast. Ten ostatni autor - 
Po drugie, wprowadzono możliwość miarkowania jego odpowiedzialności poprzez potrącenie wydatków poniesionych na rzecz wykonania kontraktu (s. 1(3)). Zauważmy, że dopuszczalność posłużenia się stosownym zarzutem nie obejmowała wszystkich wypadków utraty wcześniejszego wzbogacenia przez pozwanego. Koncepcja ograniczenia odpowiedzialności do aktualnej wysokości wzbogacenia została przyjęta - tym razem przez orzecznictwo - dopiero w latach dziewięćdziesiątych ubiegłego stulecia ${ }^{51}$.

Po trzecie, ustawa rozszerzyła zakres restytucji również na wypadki spełnienia świadczeń niepieniężnych - dostawy towarów lub realizacji usług (s. 1(3) $)^{52}$.

\section{Znaczenie Fibrosy}

Niektórzy badacze marginalizują znaczenie sprawy Fibrosy wskazując na wydany wnet po rozstrzygnięciu statut z $1943 \mathrm{r} .{ }^{53}$ Wydaje się, że ten pogląd można by zaaprobować jedynie w kontekście traktowania Fibrosy jako formalnego precedensu. $Z$ perspektywy praktycznej zmiana prawa, jaka dokonała się skutkiem orzeczenia $\mathrm{w}$ procesie Fibrosy polegała na pozbawieniu mocy wiążącej precedensu Chandler v. Webster (1904). Orzeczenie z 1942 r. przestało mieć jednak istotne znaczenie $\mathrm{w}$ momencie wejścia w życie regulacji ustawowej z 1943 r. Odtąd wystarczało powołać się na Law Reform (Frustrated Contracts) Act (1943) bez konieczności rozważania wcześniejszych precedensów.

Zauważmy jednak, że byłoby to spojrzenie niezwykle krótkowzroczne. Tym bowiem, co decyduje o fundamentalnym znaczeniu wyroku w sprawie Fibrosy dla późniejszego rozwoju prawa angielskiego, jest obiter dictum wygłoszone przez lorda Wrighta. Ten fragment jego wypowiedzi, w którym deklarował konieczność uwzględnienia bezpodstawnego wzbogacenia jako samodzielnej i niezależnej od kontraktu i deliktu podstawy praw obligacyjnych umożliwił ewolucje konstrukcji prawnych należących dziś do law of unjust enrichment (law of restitution $)^{54}$. Można powiedzieć, że otwarcie ewolucji prawa angielskiego

opierając się na Giedo van der Garde BV v. Force India Formula One Team Ltd (2010) EWHC 2373 - wskazuje na dopuszczalność restytucji, o ile przyczyna, dla której świadczono upadła w istotnym zakresie (substantial part).

51 Lipkin Gorman v. Karpnale Ltd (1991) 2 A.C. 548 (zob. także: G. McMeel, op. cit., s. 416-418, 493-497, 516-520).

52 Law Reform (Frustrated Contracts) Act (1943) 6\&7 George VI c. 40. P. Atiyah, S. Smith, Atiyah's Introduction to the Law of Contract, Oxford 2005, s. 411; P. Birks, Unjust Enrichment, Oxford 2004, s. 120; A. Burrows, op. cit., s. 698-700; P. Mitchell, op. cit., s. 248, 282-3.

53 P. Mitchell, op. cit., s. 247.

54 P. Birks, Unjust Enrichment, s. 140-142, A.T. Denning, "The Law of Restitution", by Robert Goff, Gareth Jones, London 1966, (recenzja), "LQR" 1967, nr 83, s. 277; J. Edelman, Money Had and Received: Modern Pleading of an Old Count, "Restitution Law Review" 2000, nr 8, s. 555-556. 
w tym kierunku nastąpiło właśnie w sprawie polskiej spółki Fibrosa. Niewysłowionym ratio legis ustawy z 1943 r. była już właśnie realizacja zasady bezpodstawnego wzbogacenia ${ }^{55}$.

Chociaż przyjęcie przez angielskie orzecznictwo istnienia bezpodstawnego wzbogacenia jako osobnej kategorii prawnej nastąpiło dopiero na przełomie XX i XXI wieku, to stało się to w pewnej mierze dzięki polskiej Fibrosie. W wyrokach z tego okresu wielokrotnie nawiązywano do tez stawianych przez lorda Wrighta ${ }^{56}$. Niewątpliwie kazus Fibrosa S.A. v. Fairbairn Lawson Combe Barbour Ltd (1942) zdobył miejsce w historii common law.

\section{Bibliografia}

\section{Akty prawne}

Rozporządzenie Prezydenta Rzeczypospolitej z dnia 27 października 1933 r. - Kodeks zobowiązań (Dz.U. Nr 82, poz. 598).

Ustawa z dnia 23 kwietnia 1964 r. - Kodeks cywilny (Dz.U. Nr 16, poz. 93).

Law Reform (Frustrated Contracts) Act (1943) 6\&7 George VI c. 40.

- rozporządzenie Parlamentu Europejskiego i Rady (WE) nr 593/2008 z dnia 17 czerwca 2008 r. w sprawie prawa właściwego dla zobowiązań umownych (Rzym I).

- Trading with the Enemy Act (1939) $2 \& 3$ George VI c. 86.

- ustawa z dnia 2 sierpnia 1926 r. o prawie właściwem dla stosunków prywatnych międzynarodowych.

55 Robert Goff J. (późniejszy lord Goff) w BP Exploration Co (Libya) v. Hunt (No 2) (1979) 1 W.L.R. 783 (za: A. Burrows, op. cit., s. 702). Powołany kazus jest uznawany za leading case w obszarze zagadnień związanych z wykładnią tego statutu.

56 Kiriri Cotton Co. v. Dewani (1960) A.C. 192 (lord Denning), Lipkin Gorman v. Karpnale Ltd (1991) 2 A.C. 559 (lord Templeman), Woolwich Equitable Building Society v. IRC (1993) 1 A.C. 80 (Glidewell L.J.), 135 (Ralph Gibson L.J.), 137 (Butler-Sloss L.J.), 154 (lord Keith of Kinkel), 178 (lord Jauncey of Tullichettle), 197 (lord Browne-Wilkinson), 202 (lord Slynn of Hadley), Westdeutsche Landesbank Girozentrale v. Islington London Borough Council (1996) 2 A.C. 710 (lord Browne-Wilkinson), 722 (lord Woolf), Kleinwort Benson Ltd v. Glasgow City Council (1997) 3 W.L.R. 923, (1999) 1 A.C. 186 (lord Hutton), Kleinwort Benson Ltd v. Lincoln City Council (1998) 3 WLR 1095, 406 (lord Hope of Craighead), Rowe v. Vale of White Horse (2003) EWHC 388 (Lightman J., pkt 10), Sempra Metals Limited (formerly Metallgesellschaft Limited) v. Her Majesty's Commissioners of Inland Revenue and another (2007) 3 W.L.R. 407-408 (lord Walker), Greater Manchester Police v. Wigan Athletic Afc Ltd (2007) EWHC 3095 (Ch) (Mann J., pkt 125). Co ciekawe, orzekając w sprawie Woolwich Equitable Building Society v. IRC (1993) lord Goff - zwolennik wprowadzenia law of restitution jako osobnego działu do prawa angielskiego - nie cytował omawianego dictum lorda Wrighta. Parafrazę dictum napotkamy jednak w dziele tego autora (R. Goff, G. Jones, op. cit., s. 13). J. Halberda, Zasada bezpodstawnego wzbogacenia w prawie angielskim, "Studia Prawa Prywatnego" 2014, nr 2, s. 91-113. 


\section{Orzeczenia}

Appleby v. Myers (1867) L.R. 2 C.P. 651.

BP Exploration Co (Libya) v. Hunt (No 2) (1979) 1 W.L.R. 783.

Brook's Wharf and Bull Wharf, Ltd. v. Goodman Bros.(1937) 1 K.B. 534.

Cadogan Petroleum Holdings Ltd v. Global Process Systems LLC (2013) 1 C.L.C. 733-734.

Cantiare San Rocco S.A. v. Clyde Shipbuilding and Engineering Co. Ltd. (1924) A.C. 227.

Chandler v. Webster (1904) 1 K.B. 493.

Dutch v. Warren (1720) Strange I 406.

Fibrosa Spolka Akcyjna v. Fairbairn Lawson Combe Barbour Ltd (1943) A.C. 32.

French Marine v. Compagnie Neapolitaine d'Eclairage et de Chauffage par le Gas (1921) 2 A.C. 494.

Great Peace Shipping Ltd v. Tsavliris Salvage (International) Ltd (2002) EWCA Civ 1407.

Kiriri Cotton Co. v. Dewani (1960) A.C. 192.

Krell v. Henry (1903) 2 K.B. 740.

Lipkin Gorman v. Karpnale Ltd (1991) 2 A.C. 548.

Giedo van der Garde BV v. Force India Formula One Team Ltd (2010) EWHC 2373.

Greater Manchester Police v. Wigan Athletic Afc Ltd (2007) EWHC 3095 (Ch).

Kleinwort Benson Ltd v. Glasgow City Council (1997) 3 W.L.R. 923, (1999) 1 A.C. 186.

Kleinwort Benson Ltd v. Lincoln City Council (1998) 3 WLR 1095.

London Street Tramways v. London City Council (1898) A.C. 375.

Moses v. MacFerlan (1760) 2 Burrow 1005.

Practical Statement (1966) 3 All E.R. 77.

Russkoe Obschestvo d'lia Izgstovlenia Snariadov l'voennick Pripassov v. John Stirk \& Sons (1922), Ld. 10 Ll.L.Rep.214.

Rowe v. Vale of White Horse (2003) EWHC 388.

Sempra Metals Limited (formerly Metallgesellschaft Limited) v. Her Majesty's

Commissioners of Inland Revenue and another (2007) 3 W.L.R. 407-408.

Stocznia Gdanska S.A. v. Latvian Shipping Co. Latreefer Inc. and Others (1998) 1 Lloyd's Rep. 609.

Taylor v. Caldwell (1863) 3 B. \& S. 826.

Toovey \& Anor, R (on the application of) v. Law Society (2002) EWHC 391.

United Australia v. Barclays Bank (1941) A.C. 1. 
Westdeutsche Landesbank Girozentrale v. Islington London Borough Council (1996) 2 A.C. 710.

Whincup v. Hughes (1871) L.R. 6 C.P. 78.

Woolwich Equitable Building Society v. IRC (1993) 1 A.C. 80.

\section{Literatura}

P. Atiyah, S. Smith, Atiyah's Introduction to the Law of Contract, Oxford 2005,

P. Birks, Unjust Enrichment, Oxford 2004.

G. B. Burke, The Proper Law of a Contract for the Sale of Goods, Arbitration 1924.

Burrows, A Casebook on Contract, Oxford 2009.

A.T. Denning, "The Law of Restitution”, by Robert Goff, Gareth Jones, London 1966, (recenzja), "LQR" 1967, nr 83.

N. Duxbury, Lord Wright and Innovative Traditionalism, "University of Toronto Law Journal" 2009, nr 59.

J. Edelman, Money Had and Received: Modern Pleading of an Old Count, "Restitution Law Review" 2000, nr 8.

R. Evans-Jones, Roman Law in Scotland and England and the Developement of one Law for Britain, "The Law Quarterly Review" 1999, nr 115.

R. Evans-Jones, Roman Law in Britain, [w:] Questiones Iuris. Festschrift fur Joseph Georg Wolf zum 70. Geburtstag, red. U. Manthe, C. Krampe, Berlin 2000.

R. Goff, G. Jones, The Law of Restitution, London 2002.

J. Halberda, Historia zobowiazzań quasi-kontraktowych w common law, Kraków 2012.

J. Halberda, Zasada bezpodstawnego wzbogacenia w prawie angielskim, „Studia Prawa Prywatnego" 2014, nr 2.

S. Hedley, Restitution in English Common Law, [w:] The Oxford International Encyclopedia of Legal History, red. S.N. Katz, t. V, Oxford 2009.

Ł.J. Korporowicz, Prawo rzymskie w wybranych orzeczeniach Izby Lordów w latach 1999-2009, Z dziejów prawa, t. 4 (12), Katowice 2011.

Landmark cases in the Law of Restitution, red. Ch. Mitchell, P. Mitchell, Oxford 2006.

W. Litewski, Słownik encyklopedyczny prawa rzymskiego, Kraków 1998.

Ł. Marzec, Sprawa Fibrosa vs Fairbairn. Polska spótka, Izba Lordów i prawo rzymskie, „Zeszyty Prawnicze UKSW" 2007, nr 7/1.

M. McInnes, The Reason to Reverse: Unjust Factors and Juristic Reasons, „Boston University Law Review" 2012, nr 92.

G. McMeel, Casebook on restitution, London 1996.

P. Mitchell, Fibrosa Spolka Akcyjna v Fairbairn Lawson Combe Barbour, Limited (1942), [w:] Landmark cases in the Law of Restitution, red. Ch. Mitchell, P. Mitchell, Oxford 2006. 
M. Sobczyk, Zamierzony cel świadczenia nie został osiagnięty (condictio ob rem). Przykład przydatności myśli jurystów rzymskich dla wykładni przepisów kodeksu cywilnego, „Kwartalnik Prawa Prywatnego” 2004, nr 4.

J. Strange, Reports of Adjudged Cases In the Courts of Chancery, King's Bench, Common Pleas and Exchequer, From Trinity Term in the second Year of King George I To Trinity Term in the twenty-first Year of King George II, Savoy (London) 1755.

F. Wilmot-Smith, Reconsidering "total" failure, "Cambridge Law Journal" 2013, nr 72, s. 423. 